\title{
Pemberian Makanan Pendamping Air Susu Ibu pada Bayi yang Berkunjung ke Unit Pediatri Rawat Jalan
}

\author{
Soepardi Soedibyo, Winda F
}

Latar belakang. Makanan pendamping (MP) ASI harus diberikan mulai usia 6 bulan karena mulai usia ini bayi sangat rentan untuk terjadi malnutrisi. Namun, pemberian MP-ASI terlalu dini mempunyai dampak yang kurang baik pada bayi.

Tujuan. Untuk mengetahui pengetahuan orangtua mengenai MP-ASI tentang usia pemberian, alasan ibu memberikannya jenis MP-ASI dan cakupan pemberian ASI eksklusif.

Metoda. Penelitian deskriptif dengan desain potong lintang, dilakukan pada orang tua pasien yang membawa anaknya berusia 1-12 bulan, yang sudah diberikan makanan pendamping untuk berobat di Pediatri Rawat Jalan, RS Dr. Cipto Mangunkusumo Jakarta.

Hasil. Responden perempuan lebih banyak dari pada laki-laki, usia berkisar 17-38 tahun, pendidikan mulai SD sampai perguruan tinggi. Memberikan MP-ASI $<4$ bulan pada 12 responden (12,63\%), 4-6 bulan 80 responden $(84,21 \%)$ dan 3 responden memberikan pada usia $>6$ bulan (3,6 \%). Jenis MP-ASI berupa air tajin, bubur susu, buah-buahan dan biskuit. Jumlah bayi yang mendapat susu formula $9(9,47 \%)$.

Kesimpulan. Delapan puluh empat persen orang tua memberikan MP-ASI pada usia bayi sesuai anjuran WHO yaitu usia 4-6 bulan. Makanan pendamping ASI yang diberikan pada anak yang termuda adalah air tajin dan air kaldu ceker ayam. Cakupan pemberian ASI eksklusif 6,3\%, sedangkan jumlah bayi yang hanya diberi susu formula 9,47 \%.

Kata kunci: ASI eksklusif, makanan pendamping ASI

$C$ etika air susu ibu (ASI) tidak mencukupi kebutuhan nutrisi bayi, maka makanan pendamping ASI (MP-ASI) harus diberikan sebagai makanan tambahan. Perubahan kebutuhan

\footnotetext{
Alamat korespondensi:

Dr. Soepardi Soedibyo, Sp.A(K).

Pediatri Rawat Jalan Dep. Ilmu Kesehatan Anak FKUI. Divisi Nutrisi dan metabolik. Departemen Ilmu Kesehatan Anak FKUI-RSCM.

Jl. Salemba no.6, Jakarta 10430.

Telepon: 021-3915179. Fax: 021-390 7743 .
}

Dr. Winda F. PPDS IKA RSCM dari ASI eksklusif ke makanan pendamping umumnya terjadi pada usia 6-24 bulan, dan periode ini sangat sensitif untuk terjadinya malnutrisi pada anak. Menurut WHO, 2 dari 5 anak di negara yang pendapatan perkapita rendah menderita malnutrisi. ${ }^{1}$ Penambahan MP harus dimulai pada usia 6 bulan; nilai gizi MP harus adekuat seperti kandungan dalam ASI, bersih, rasa dan bentuk yang menarik dalam jumlah yang cukup. WHO menyarankan bahwa bayi harus menerima MP pada usia 6 bulan 2-3 kali sehari disamping ASI sampai usia 8 bulan dan meningkat menjadi 3-4 kali pada usia 9-11 bulan dan pada usia 
12-24 bulan tambahan MP 1-2 kali perhari. ${ }^{2}$ WHO menyepakati bahwa umur yang tepat untuk pemberian MP-ASI adalah usia 6 bulan dan dikatakan tidak ada untungnya memberikan MP-ASI pada usia kurang dari 6 bulan. ${ }^{3,4}$

Makanan pendamping tidak menggantikan ASI, tetapi secara bertahap menambahkan sesuai kebutuhan gizi bayi. Keberhasilan pemberian MP ini dipengaruhi juga oleh perkembangan fungsi sistem syaraf, saluran cerna dan ginjal bayi. ${ }^{4}$ Air susu ibu merupakan makanan bayi terbaik dan alami. Air susu ibu dengan komposisi yang unik, diciptakan oleh Tuhan Yang Maha Kuasa sesuai dengan kebutuhan tumbuh kembang bayi. Air susu ibu mengandung zat antibodi humoral dan selular sehingga morbiditas bayi yang mendapat ASI lebih rendah dibanding dengan bayi yang mendapat susu formula. ${ }^{5}$

Air susu ibu mengandung enzim-enzim yang membantu pencernaan dan juga enzim yang berfungsi sebagai antibakteri seperti lisozim, katalase dan peroksidase. Selain itu ASI mengandung hormonhormon seperti ACTH, TRH, TSH, EGH, prolaktin, kortikosteroid, prostaglandin dll. Pemberian ASI, mempunyai dampak pada ibu yaitu mengurangi perdarahan postpartum, mempercepat involusi uterus dan menunda kembalinya kesuburan., ${ }^{5,6}$ Pemberian ASI dianjurkan sampai anak berusia 2 tahun yaitu usia anak dapat makan makanan padat dengan baik. Diet ibu mempengaruhi kandungan nutrien dalam ASI. Diet ibu yang mengandung rendah vitamin A dan DHA akan menyebabkan kandungan vitamin A dan DHA dalam ASI rendah. Tidak ada pantangan diet pada ibu yang menyusui; pemberian ASI dengan cara yang baik dapat mendekatkan hubungan batin antara ibu dan bayi sehingga menimbulkan rasa aman dan tenang. Walaupun demikian, tidak semua ibu memproduksi ASI yang cukup, sehingga diperlukan makanan pendamping ataupun makanan pengganti. ${ }^{7}$ Pemerintah telah membuat standar nutrisi susu formula yang boleh masuk ke Indonesia. Pemberian makanan pendamping ini harus disesuaikan dengan maturasi saluran cerna bayi dan kebutuhannya. Sebaiknya dimulai pada usia 4-6 bulan. Di Indonesia masih berkembang mitos dalam masyarakat, agar bayi berkembang dengan cepat dan tumbuh sehat harus segera diberikan makanan tambahan.

Telah dilakukan penelitian mengenai pengetahuan orang tua tentang bagaimana pemberian MP-ASI pada bayi yang dibawa berobat ke Poliklinik Umum Pediatri
Rawat Jalan Ilmu Kesehatan Anak RS. Ciptomangunkusumo, Jakarta. Tujuan penelitian ini untuk mengetahui gambaran pemberian MP-ASI pada bayi, mengetahui pengetahuan ibu tentang usia bayi yang tepat mulai diberikan MP-ASI, alasan ibu mulai memberikan MP-ASI, mengetahui jenis MP-ASI yang diberikan dan mengetahui cakupan pemberian ASI eksklusif. Manfaat penelitian ini untuk bidang pelayanan dan edukasi orang tua/masyarakat mengenai pola pemberian MP-ASI agar bayi dapat tumbuh kembang secara optimal.

\section{Metoda}

Penelitian deskriptif dengan desain potong lintang, dilakukan pada orang tua pasien yang datang membawa anaknya yang berusia 1 sampai dengan 12 bulan sudah mendapat padat makanan pendamping berobat ke Unit Pediatri Rawat Jalan RS. Dr. Cipto Mangunkusumo, Jakarta. Pemilihan subyek penelitian dilakukan dengan cara consecutive sampling, semua orang tua atau pengasuh pasien yang memenuhi kriteria penerimaan. Penelitian dilakukan mulai pada 1 Juni sampai dengan 30 September 2006 dengan cara wawancara dan pemeriksaan fisis kemudian data yang didapat dimasukkan ke formulir penelitian untuk selanjutnya diolah. Hasil dilaporkan secara tertulis.

\section{Hasil Penelitian}

Responden yang memenuhi kriteria penerimaan 105 orang. Karakteristik responden tertera pada Tabel 1.

Pada penelitian ini jumlah pasien laki-laki hampir sama dengan perempuan. Terdapat 22 pasien yang berusia $<4$ bulan, tetapi yang diikutsertakan dalam penelitian ini hanya 12 orang karena sudah mendapat MP-ASI.

\section{Diskusi}

Pemberian makanan pada bayi adalah topik yang kompleks karena berdampak tidak hanya pada kesehatan dan status gizi bayi, tetapi juga pada perkembangan psikologis dan untuk membentuk kebiasaan makan yang benar. Kebiasaan makan yang benar dapat berpengaruh pada kesehatan dan status 
gizi anak di kemudian hari. Di sisi lain, pemberian makan pada bayi juga dipengaruhi oleh sikap dan nilai yang diyakini orangtua dan sangat berkaitan erat dengan hubungan sosial dan budaya. Air susu ibu dan susu formula menyediakan semua kebutuhan nutrisi bayi selama minimal 6 bulan pertama kehidupan. Pemberian makan pada bayi/anak mempunyai beberapa tujuan, yaitu memenuhi kebutuhan zat makanan yang adekuat untuk keperluan hidup,

Tabel 1. Karakteristik responden

\begin{tabular}{|c|c|}
\hline Karakteristik & Jumlah \\
\hline \multicolumn{2}{|l|}{ Jenis kelamin } \\
\hline - perempuan & 80 \\
\hline - laki- laki & 15 \\
\hline \multicolumn{2}{|l|}{ Usia (tahun) } \\
\hline - $17-20$ & 14 \\
\hline - $>20-25$ & 26 \\
\hline - $>25-30$ & 37 \\
\hline - $>30-35$ & 12 \\
\hline - $>35$ & 6 \\
\hline \multicolumn{2}{|l|}{ Pendidikan responden } \\
\hline - Sekolah dasar & 12 \\
\hline - SMP atau sederajat & 41 \\
\hline - SMA atau sederajat & 39 \\
\hline - Akademi atau sarjana & 3 \\
\hline \multicolumn{2}{|c|}{ Pengetahuan usia bayi terbaik mulai diberikan MP-ASI (bulan) } \\
\hline - 3 & 12 \\
\hline - 4 & 61 \\
\hline - 6 & 19 \\
\hline - 8 & 3 \\
\hline \multicolumn{2}{|l|}{ Jenis makanan pendamping } \\
\hline - Pisang & 105 \\
\hline - Air jeruk & 78 \\
\hline - Air tomat & 24 \\
\hline - Air tajin & 12 \\
\hline - Air kaldu ceker ayam & 9 \\
\hline - Bubur susu & 92 \\
\hline - Kue/biskuit & 57 \\
\hline
\end{tabular}

memelihara kesehatan dan untuk aktivitas sehari-hari, menunjang tercapainya tumbuh kembang yang optimal dan mendidik anak supaya terbina mempunyai selera dan kebiasaan makan yang sehat, memilih dan menyukai makanan sesuai kebutuhan anak. ${ }^{6}$ Saat memulai diberikan MP-ASI harus disesuaikan dengan maturasi saluran cerna bayi dan kebutuhannya. Sebaiknya makanan padat mulai diberikan pada usia 4-6 bulan. Pada usia tersebut, bayi sudah mampu melakukan koordinasi mengisap, menelan dan bernapas $^{7}$

\section{Usia pemberian makanan pendamping ASI}

Pemberian MP-ASI pada usia < 4 bulan pada penelitian ini dijumpai pada 12 dari 95 pasien. Sedangkan pemberian MP-ASI pada usia $4-6$ bulan dijumpai pada 70 di antara 95 pasien $(73,7 \%)$. Hasil penelitian di Honduras menunjukkan bahwa pemberian MP-ASI yang lebih dini pada bayi berat lahir rendah ternyata tidak memberikan manfaat dalam meningkatkan pertumbuhan. ${ }^{8}$

Pemberian MP-ASI sebelum usia 4 bulan dapat disebabkan pengetahuan yang tidak memadai tentang cara pemberian makan untuk bayi. Di Indonesia terutama di daerah pedesaan secara tradisional sering kita jumpai pemberian MP-ASI mulai beberapa hari setelah bayi lahir. Kebiasaan ini kurang baik, karena pemberian makanan pendamping ASI terlalu dini dapat mengakibatkan bayi lebih sering menderita diare. Hal ini disebabkan pembentukan zat anti oleh usus bayi belum sempurna dan mungkin juga cara menyiapkan makanan yang kurang bersih. Bayi mudah alergi terhadap zat makanan tertentu. Keadaan ini terjadi akibat usus bayi masih permeabel, sehingga mudah dilalui oleh protein asing. Bila makanan yang diberikan kurang bergizi dapat mengakibatkan anak menderita kurang gizi atau terjadi malnutrisi, dapat pula terjadi overfeeding. ${ }^{8}$ Akibat lain adalah produksi ASI akan cepat menurun karena frekuensi menyusu

Tabel 2. Usia bayi mulai diberikan MP-ASI berdasarkan pendidikan responden

\begin{tabular}{lccc}
\hline \multirow{2}{*}{ Tingkat pendidikan responden } & \multicolumn{3}{c}{ Usia bayi mulai diberikan MP - ASI (bulan) } \\
\cline { 2 - 4 } & $<\mathbf{4}$ & $\mathbf{4 - 6}$ & $>\mathbf{6}$ \\
\hline Sekolah dasar & 10 & 2 & 0 \\
SMP atau sederajat & 2 & 36 & 3 \\
SMA atau sederajat & 0 & 39 & 0 \\
Akademi atau perguruan tinggi & 0 & 3 & 0 \\
\hline
\end{tabular}


menjadi lebih jarang, bayi sudah kenyang dengan MPASI. Tingginya solute load dari MP-ASI yang diberikan dapat menimbulkan hiperosmolaritas yang meningkatkan beban ginjal.

Alasan pemberian makanan pendamping ASI pada usia $4-6$ bulan adalah kebutuhan energi bayi untuk pertumbuhan dan aktivitas fisik makin bertambah, sedangkan produkasi ASI relatif tetap. Pada usia 4 bulan bayi sudah mengeluarkan air liur lebih banyak dan produksi enzim amilase lebih banyak sehingga bayi siap menerima makanan lain selain ASI. Dalam proses menelan pada usia tersebut, apabila makanan disuapkan ke dalam mulutnya bayi sudah dapat menutup mulutnya dengan rapat dan menggerakkan lidah ke muka dan ke atas untuk mendorong makanan ke belakang,untuk ditelan. Pada saat inilah bayi diberikan kesempatan mempraktekkan kepandaiannya tersebut dengan memberikan makanan lumat.

Tabel 3. Karakteristik pasien

\begin{tabular}{|c|c|}
\hline Karakteristik bayi & Jumlah \\
\hline \multicolumn{2}{|l|}{ Usia (bulan) } \\
\hline - $<4$ & 12 \\
\hline - $4-6$ & 24 \\
\hline - $>6-8$ & 31 \\
\hline - $\quad>8-10$ & 12 \\
\hline - $\quad>10-12$ & 16 \\
\hline \multicolumn{2}{|l|}{ Jenis kelamin } \\
\hline - Laki-laki & 48 \\
\hline - Perempuan & 47 \\
\hline \multicolumn{2}{|l|}{ Pemberian ASI } \\
\hline - ASI eksklusif & 6 \\
\hline - ASI ditambah susu formula & 82 \\
\hline - Susu formula saja & 9 \\
\hline \multicolumn{2}{|c|}{ Usia mulai diberikan MP - ASI (bulan) } \\
\hline - $<4$ & 12 \\
\hline - $4-6$ & 70 \\
\hline$\cdot>6-8$ & 13 \\
\hline
\end{tabular}

Dengan bertambah matangnya kemampuan oromotor, bayi usia 6-9 bulan mulai belajar mengunyah dengan menggerakkan rahang ke atas dan ke bawah, sehingga dapat diberikan makanan yang lebih kasar. Demikian juga dengan kemampuan motorik halus pada awalnya bayi memegang dengan kelima jari tangannya kemudian pada umur 9 bulan bayi sudah dapat menjimpit, maka untuk mengembangkan kemampuan tersebut, bayi dapat diberikan makanan yang dapat dipegang sendiri atau makanan kecil yang dapat dijimpit. Pada usia $6-7$ bulan bayi sudah dapat duduk, sehingga dapat diberikan makanan dalam posisi duduk. Pada usia 6 - 9 bulan bibir bayi sudah dapat mengatup rapat pada cangkir, sehingga dapat dilatih minum memakai cangkir atau gelas.

\section{Pengetahuan ibu tentang usia yang tepat bayi mulai diberikan MP-ASI}

Di antara 95 responden, 12 menjawab usia terbaik bayi mulai diberikan MP-ASI adalah usia < 4 bulan, 83 responden pada usia 4-6 bulan, tetapi 3 diantaranya memberikan MP-ASI mulai usia 8 bulan karena jumlah ASI nya dirasakan masih cukup dan bayinya tidak suka dengan MP-ASI yang diberikannya. Responden mengetahui ASI bahwa maupun susu formula menyediakan semua kebutuhan nutrisi bayi pada masa pertama kehidupan dan selanjutnya akan membutuhkan Makanan Pendamping secara bertahap. Sembilan puluh responden memberikan MP-ASI pada usia yang dianjurkan WHO yaitu usia 4-6 bulan. Saat yang tepat untuk pemberian MP-ASI secara mudah dapat ditentukan dengan melihat kemampuan bayi tersebut yaitu dapat duduk tanpa bantuan dan sudah mampu mengontrol gerakan kepalanya. Pemberian dimulai jika sesudah pemberian ASI atau susu formula, bayi masih tampak lapar. ${ }^{6}$

Pemberian MP-ASI disesuaikan dengan perkembangan saluran cerna bayi yang belum sempurna.

Tabel 4. Usia awal pemberian MP-ASI berdasarkan berat badan lahir

\begin{tabular}{lccc}
\hline \multirow{2}{*}{ Berat badan lahir (gram) } & \multicolumn{3}{c}{ Usia bayi mulai diberikan MP - ASI (bulan) } \\
\cline { 2 - 4 } & $<4$ & $4-6$ & $>6$ \\
\hline$<2000$ & 2 & 11 & 0 \\
$2000-2500$ & 8 & 21 & 0 \\
$>2500-3000$ & 1 & 33 & 0 \\
$>3000-3500$ & 1 & 11 & 2 \\
$>3500$ & 0 & 4 & 1 \\
\hline
\end{tabular}


Dengan pemberian MP-ASI terlalu dini, telah diketahui dapat menimbulkan beberapa masalah. ${ }^{7}$ Perlunya menunda pemberian MP-ASI hingga usia 4 bulan adalah untuk mencegah kemungkinan overfeeding karena bayi tersebut belum mampu memberikan pertanda bahwa ia sudah kenyang. Umumnya dengan cara membalikkan muka atau badan atau wajah yang memperlihatkan tidak berminat terhadap makanan tersebut lagi. Alasan lain adalah bayi belum mampu menelan MP-ASI dengan benar dan berpotensi untuk tersedak dan tidak dapat tidur nyenyak pada malam hari.?

Terdapat 2 bayi dengan berat badan lahir $1500 \mathrm{~g}$. Oleh orangtuanya diberikan MP-ASI berupa air tajin pada usia 2 bulan. Status gizi pasien tersebut pada usia 4 bulan pada saat pemeriksaan termasuk gizi baik. Delapan pasien dengan berat badan lahir 2000-2500 g mendapat makanan pendamping berupa buah-buahan dan air kaldu ceker ayam pada usia $<4$ bulan dengan alasan supaya lekas besar dan sehat. Satu pasien dengan berat badan lahir $3200 \mathrm{~g}$ dan 1 pasien lainnya diberikan MP-ASI karena produksi ASI sudah berkurang dan ibunya karyawan yang pulang malam. Pemberian MPASI dapat dipengaruhi oleh berat lahir. Hasil survey yang dilakukan di Inggris pada tahun 2000 menunjukkan bahwa bayi yang lahir dengan berat lahir rendah, lebih tinggi angka pemberian MP-ASI di bawah usia 4 bulan. ${ }^{8}$ Pemberian makanan pendamping ini tidak meningkatkan pertumbuhan bayi. ${ }^{8,9}$ Bayi dengan berat lahir $>3800$ g cenderung mendapat makanan pendamping ASI lebih dini karena bayi menunjukkan rasa laparnya atau ibu mengira bayi kurang kenyang. ${ }^{9}$ Pada penelitian ini semua bayi dengan berat lahir $>3500 \mathrm{~g}$ mendapat makanan pendamping ASI pada usia 4-6 bulan. Namun oleh karena bayi dengan berat lahir $>3500$ g hanya 5 orang, sehingga sulit untuk mengambil kesimpulan tentang pengaruh pemberian MP-ASI dengan berat badan lahir.

Untuk memperkenalkan jenis MP-ASI pada awalnya harus dipilih makanan yang mudah dicernakan berasal dari karbohidrat, kemudian diberikan tambahan protein dan akhirnya lemak dalam bentuk cairan dan secara bertahap berubah ke makanan semi solid. Pada penelitian ini seorang pasien dengan berat badan waktu lahir $1500 \mathrm{~g}$ diberikan ASI ditambah dengan air tajin dan seorang lagi dengan air kaldu ceker ayam dengan alasan makanan sehat. Jenis makanan pendamping lainnya adalah buah-buahan bubur susu dan biskuit. Makanan pendamping ASI adalah makanan yang secara berangsur diberikan kepada bayi untuk memenuhi kebutuhan gizi bayi menjelang dan sesudah disapih, termasuk antara lain bubur susu, buah, sayuran, nasi tim, telur, biskuit dan lain-lain.

Dari tiga ibu yang berpendidikan tinggi tidak ada yang memberikan MP-ASI pada usia < 4 bulan. Semuanya memberikan pada usia 4-6 bulan karena pernah mendapatkan informasi dari dokternya. Dari 49 responden yang berpendidikan SMA terdapat 3 ibu yang memberikan MP-ASI pada usia > 6 bulan.karena ASI nya dirasakan masih cukup. Pada usia 4-6 bulan MP-ASI dapat dimulai dengan pemberian 1-2 sendok air jeruk/ hari, dan jumlahnya dapat ditambah secara bertahap sesuai dengan keinginan bayi. Jika air jeruk ini terlalu kental dapat diencerkan, jika terlalu dingin jangan dipanaskan karena akan merusak vitamin $\mathrm{C}$ yang dikandungnya. Pemberian air sup yang jernih beberapa sendok dapat ditingkatkan kekentalannya.dengan menambahkan beras dalam pembuatannya. Saat ini banyak tersedia MP-ASI di toko makanan bayi, dikenal sebagai Cerelac, Farex, Nestum dan lain-lain. Pemberian buahbuahan seperti pisang, pepaya, juice mangga atau apel dapat diberikan sesuai selera bayi

Pendidikan ibu sangat berpengaruh terhadap tumbuh kembang bayi. Ibu dengan pendidikan yang tinggi diharapkan memiliki pengetahuan yang memadai tentang tumbuh kembang bayi. Pada penelitian ini hanya tiga orang ibu yang berpendidikan tinggi dan semuanya memberikan makanan pendamping ASI sesuai waktu yang dianjurkan. Mungkin terdapat faktor lain yang mempengaruhi perilaku ibu selain pendidikan, seperti pengaruh lingkungan sosial, adat istiadat dan kebiasaan di keluarga. Seperti diketahui di Indonesia masih banyak keluarga yang bersifat extended family, yaitu di dalam keluarga terdapat anggota keluarga lain yang bukan keluarga inti seperti nenek dan kakek, atau paman dan bibi. Pengaruh extended family mungkin cukup berperan dalam mempengaruhi perilaku ibu dalam memberikan MP-ASI untuk bayinya. Pendidikan ibu pada penelitian ini memberikan dampak yang baik karena 63,3\% responden berpendidikan perguruan tinggi dan SMA memberikan MP-ASI pada usia yang dianjurkan 4-6 bulan.

Dari 95 responden hanya terdapat 6 responden $(6,3 \%)$ yang memberikan ASI eksklusif hingga 6 dan 9 bulan. Sebanyak $82(86.3 \%)$ responden memberikan ASI ditambah susu formula, dan terdapat 5 responden $(5,3 \%)$ yang saat diwawancara 
menyatakan tidak pernah memberikan ASI untuk bayinya. ASI eksklusif merupakan makanan terbaik untuk bayi yang berusia $0-6$ bulan. Pemberian ASI eksklusif selama 4-6 bulan pertama kehidupan bayi dianjurkan oleh WHO. ${ }^{10}$ Angka cakupan pemberian ASI eksklusif pada penelitian ini rendah karena hanya ditemukan pada 6 dari 95 responden. Hal ini mungkin disebabkan banyak dari responden yang bekerja dengan waktu lebih panjang dari waktu harus memberikan ASI, sehingga responden menggantinya dengan susu formula. Upaya promosi ASI eksklusif perlu ditingkatkan lagi terutama untuk ibu yang tidak bekerja diluar rumah. Pemberian susu formula saja pada penelitian ini didapatkan pada 9 responden dan 82 responden memberikan susu formula bersamasama ASI. Angka diatas cukup tinggi. Tingginya penggunaan susu formula mungkin disebabkan karena gencarnya promosi susu formula di media massa atau pun promosi langsung ke tenaga kesehatan. Lima pasien diberikan susu formula sejak lahir oleh bidan di rumah sakit karena ASI tidak keluar. Selain itu susu formula diberikan segera karena masa cuti melahirkan sudah habis dan ibu harus segera bekerja kembali dan meninggalkan bayinya. Pendidikan yang tinggi ternyata tidak menjamin pemberian ASI eksklusif terlaksana. Sebagian besar responden berpendidikan menengah dan pendidikan tinggi namun upaya untuk memberikan ASI eksklusif tidak sebanding dengan tingginya tingkat pendidikan.

\section{Kesimpulan}

Pemberian MP-ASI usia 4-6 bulan pada pasien yang berobat ke Poliklinik Umum Ilmu Kesehatan Anak RS.Ciptomangunkusumo, Jakarta dijumpai pada 85,7 $\%$ responden. Orang tua pasien telah mengetahui usia yang tepat untuk bayi mulai diberikan MP- ASI. Jenis MP-ASI tersering yang diberikan pertama kali sebelum usia 4 bulan adalah bubur susu encer, walaupun satu responden memberikan air tajin dan seorang lagi memberikan air kaldu ceker ayam. Pemberian ASI eksklusif pada penelitian ini terdapat pada 6 di antara 95 (6,3\%). Dalam masyarakat Indonesia masih banyak mitos yang berkembang bahwa agar bayi sehat dan cepat besar segera diberikan MP-ASI. Maka disarankan saat mengunjungi pusat layanan kesehatan masyarakat kepada ibu atau pengasuh anak harus diberikan pengetahuan tentang pola pemberian MP-ASI yang tepat untuk bayi.

\section{Daftar Pustaka}

1. Complimentary feeding: Report of the global consultation and summary of guiding principles for complimentary feeding of the breastfed child Geneva, World Health Organization, 10-13 Desember 2001.

2. Report of informal meeting to review and develop indications for complimentary feeding, Washington D.C, 3-5 December 2002.

3. Neylon A. 2000. Statement circulated at Technical Consultation on infant feeding. The ACC ISCN working group in breast feeding and complimentary feeding, Washington, Maret 2000.

4. Greiner T. Sustained breastfeeding, complementation and care Food and Nutrition Bull 1995; 16:313-9.

5. Starting solid food for infant. Diunduh dari: www.framinghampediatircs.com. Diakses tanggal 1 Agustus 2006.

6. Soetjiningsih, Suandi IKG. Gizi untuk tumbuh kembang anak. Dalam: Narendra MB, Sularyo TS, Soetjiningsih, Suyitno H, Ranuh ING, penyunting. Tumbuh kembang anak dan remaja. Edisi ke-1. Jakarta: Sagung Seto, 2002. h. 22-47.

7. Dewey KG, Cohen RJ, Brown KH, Rivera LL. Age of introduction of complementary foods and growth of term, low birth weight, breast-fed infants: a randomized intervention study in Honduras. Am J Clin Nutr 1999; 69:678-86.

8. Forsyth JS, Ogston SA, Clark A, Florey CD, Howie PW. Rellation between early introduction of solid food to infants and their weight and illnesses during the first two years of life. BMJ 1993; 302:1572-6.

9. Hamlyn B, Brooker S, Oleinikova K, Wands S. Infant feeding 2000: a survey conducted on behalf of the Department of Health. The Scottish Executive, The National Assembly for Wales and the Department of Health, Social Services and Public Safety in Northern Ireland. London: The Stationary office, 2002. h. 163-86.

10. Kliegman RM. The feeding of infant and children. Dalam: Behrman RE, Kliegman RM, Jenson Hb, penyunting. Nelson Texbook of Pediatrics. Edisi ke-16. Philadelphia: WB Saunders Company, 2000. h. 151-65. 